\title{
Anti-CA6-DM4 Immunoconjugate SAR566658
}

National Cancer Institute

\section{Source}

National Cancer Institute. Anti-CA6-DM4 Immunoconjugate SAR566658. NCI Thesaurus. Code C95764.

An immunoconjugate consisting of a humanized monoclonal antibody against the tumor-associated sialoglycotope CA6 (huDS6) conjug ated to the cytotoxic maytansinoid DM4, with potential antineoplastic activity. The anti-CA6 monoclonal antibody moiety of SAR566658 targets and binds to the cell surface antigen CA6. Upon antibody/antigen binding and internalization, the immunoconjugate releases DM4, which binds to tubulin and disrupts microtubule assembly/disassembly dynamics, resulting in inhibition of cell division and cell growth of CA6-expressing tumor cells. The CA6 epitope is found on a variety of solid tumors, including breast, ovarian, cervical, lung and pancreatic tumors. 